\title{
THE EFFECTS OF BORON DERIVATIVES AS PRETREATMENT CHEMICALS FOR BIODEGRADATION OF SUNFLOWER STALKS
}

\author{
Ayhan Tozluoğlu,
}

\begin{abstract}
This study examined the suitability of boron derivatives as pretreatment chemicals with regard to their efficiency in the enzymatic saccharification of sunflower stalks. It was hypothesized that the utilization of boron derivatives might improve enzymatic digestibility. The aim of this study was to examine the effect of $\mathrm{NaOH}$ and the boron derivatives sodium borohydride $\left[\mathrm{NaBH}_{4}\right]$ calcined tincal $\left[\mathrm{Na}_{2} \mathrm{~B}_{4} \mathrm{O}_{7}(1-5) \mathrm{H}_{2} \mathrm{O}\right]$, colemanite $\left[\mathrm{CaB}_{3} \mathrm{O}_{4}(\mathrm{OH})_{3} \mathrm{H}_{2} \mathrm{O}\right]$, boron oxide $\left[\mathrm{B}_{2} \mathrm{O}_{3}\right]$, borax decahydrate $\left[\mathrm{Na}_{2} \mathrm{~B}_{4} \mathrm{O}_{7} 10 \mathrm{H}_{2} \mathrm{O}\right]$, disodium octaborate tetrahydrate $\left[\mathrm{Na}_{2} \mathrm{~B}_{8} \mathrm{O}_{13} 4 \mathrm{H}_{2} \mathrm{O}\right]$ and boric acid $\left[\mathrm{H}_{3} \mathrm{BO}_{3}\right]$ on enzymatic saccharification. Results showed that the boron derivatives prevented peeling reactions and preserved more glucan; however, the $\mathrm{NaOH}$ removed the highest amounts of xylan and lignin from the structure. Significant xylan removal was observed with $\mathrm{H}_{3} \mathrm{BO}_{3}$, while $\mathrm{B}_{2} \mathrm{O}_{3}$ was as effective as $\mathrm{NaBH}_{4}$ and $\mathrm{NaOH}$ for selective lignin removal. The highest enzymatic saccharification yield $(59,5 \%)$ resulted with the $2 \% \mathrm{NaOH}$ pretreatment, whereas slightly lower yields were achieved with some boron derivatives $\left(1 \% \mathrm{NaBH}_{4}-45 \% ; 2 \% \mathrm{~B}_{2} \mathrm{O}_{3}-40,2 \%\right.$; and $\left.2 \% \mathrm{H}_{3} \mathrm{BO}_{3}-36,7 \%\right)$.
\end{abstract}

Keywords: Enzymatic hydrolysis, enzymatic saccharification, glucan, lignin, xylan.

\section{INTRODUCTION}

Sunflower seeds are the third largest source of vegetable oil production, the other valuable sources being soybean and palm (Vaithanomsat et al. 2009). Turkey is one of the top ten sunflower-producing countries in the world, with nearly $3 \%$ of the world's sunflower production and $6 \%$ of the acreage (Anonymous 2014a). In recent years, Turkish sunflower acreage and crop production have increased from 500000 to 600000 ha and from 800000 to 1,4 million tons, respectively (Anonymous 2014b). The usage of stalks, heads and leaves for medicinal and cosmetic purposes is very limited and, generally, after harvest these materials are left in the fields to be burnt, causing environmental pollution (Sharma et al. 2002). The huge volume of these lignocellulose residues (3-7 tons of dry matter/ha) emerging annually (Marechal and Rigal 1999) can become an important low-cost source of materials that can be converted into valuable products such as ethanol. The industrial use of this substrate in bioethanol production may also result in decreasing the soil and air pollution associated with the disposal of the stalks.

Sunflower stalks consist mainly of cellulose, hemicelluloses and lignin in the structure, which is similar to woody biomass. The presence of lignin, and its complex distribution in the cell wall structure, and the crystalline nature of cellulose have motivated researchers to develop several pretreatment techniques which have further improved the effectiveness of enzymatic hydrolysis in reducing the cost of fermentation (Wingren et al. 2005).

The main approach of the research dealing with pretreatments is to improve the accessibility of cellulose to hydrolytic enzymes while decreasing hemicellulose and cellulose degradation during the

${ }^{1}$ Faculty of Forestry, Forest Products Engineering Department, Duzce University, Duzce, Turkey.

•Corresponding author: ayhantozluoglu@duzce.edu.tr

Received: 11.01.2016 Accepted: 02.08.2016 
application. Carbohydrate degradation and by-products that emerge during the degradation lower the ethanol yield by diminishing the hydrolysis and fermentation processes. This is due to the inhibitory effects of these by-products (Ohgren et al. 2007). Thus, the goal of this research is to improve the efficiency of the pretreatments by increasing the conversion rate in order to generate a higher economic benefit.

In this context, the effects of physicochemical pretreatments like hydrothermal (Diaz et al. 2011, Eom and Yu 2015) and steam explosion (Ruiz et al. 2008, Sharma et al. 2002), and of chemical pretreatments like alkali (Soto et al. 1994), hydrochloric acid (Bonilla et al. 1990), sulfuric acid (Jimenez and Bonilla 1993, Tosun 1997, Ruiz et al. 2013) and peracetic acid (Farid et al. 1983) have been studied for sunflower stalks. Additionally, Sharma et al. (2002) and Ruiz et al. (2006) have examined the fermentation and ethanol production from sunflower stalks.

Several pretreatment techniques have been devised to enhance the efficiency of enzymatic saccharification and thus bioethanol production, and chemical pretreatments have already been followed by the environmentally friendly enzymatic hydrolysis. The conventional pretreatment chemical utilized in this context is usually sodium hydroxide $(\mathrm{NaOH})$, as well as other chemicals including peroxide $\left(\mathrm{H}_{2} \mathrm{O}_{2}\right)$, sulfuric acid $\left(\mathrm{H}_{2} \mathrm{SO}_{4}\right)$ etc. Studies on alternative chemicals like sodium borohydride $\left(\mathrm{NaBH}_{4}\right)$ are very limited in the literature. Copur et al. $(2012,2013 \mathrm{a}, 2013 \mathrm{~b})$ examined the selective capability of $\mathrm{NaBH}_{4}$ as a pretreatment chemical, and they observed it to be as effective as $\mathrm{NaOH}$ for wheat straw, corn stalks and hazelnut husks. In addition, as Turkey has $71,3 \%$ of the world boron reserves, it is important to examine boron derivatives as pretreatment chemicals. It was hypothesized that some of the boron derivatives utilized in this study could improve the enzymatic digestibility. Therefore, the aim of this study was to examine the effect of several boron derivatives on enzymatic saccharification. Consequently, sunflower stalks were treated with the conventional pretreatment chemical, $\mathrm{NaOH}$, and the results were compared with sodium borohydride $\left[\mathrm{NaBH}_{4}\right]$ and other boron derivatives utilized for the first time for this purpose including calcined tincal $\left[\mathrm{Na}_{2} \mathrm{~B}_{4} \mathrm{O}_{7}(1-5) \mathrm{H}_{2} \mathrm{O}\right]$, colemanite $\left[\mathrm{CaB}_{3} \mathrm{O}_{4}(\mathrm{OH})_{3} \mathrm{H}_{2} \mathrm{O}\right]$, boron oxide $\left[\mathrm{B}_{2} \mathrm{O}_{3}\right]$, borax decahydrate $\left[\mathrm{Na}_{2} \mathrm{~B}_{4} \mathrm{O}_{7} 10 \mathrm{H}_{2} \mathrm{O}\right]$, disodium octaborate tetrahydrate $\left[\mathrm{Na}_{2} \mathrm{~B}_{8} \mathrm{O}_{13} 4 \mathrm{H} 2 \mathrm{O}\right]$ and boric acid $\left[\mathrm{H}_{3} \mathrm{BO}_{3}\right]$.

\section{MATERIALS AND METHODS}

\section{Materials}

Sunflower stalks, obtained from the field in Turkey right after harvest, were cut to suitable sizes $(3-5 \mathrm{~cm})$ using a garden chopper. The chopped material was air dried at room temperature and stored in plastic bags. The moisture content was determined (Tappi T $412 \mathrm{om}-06$ ) and the material was stored at $-5^{\circ} \mathrm{C}$. 


\section{Methods}

\section{Chemical pretreatments}

Solid material (40 g o.d.) was chemically treated with conventional sodium hydroxide $(\mathrm{NaOH})$ as control, and with boron derivatives of sodium borohydride $\left[\mathrm{NaBH}_{4}\right]$, calcined tincal $\left[\mathrm{Na}_{2} \mathrm{~B}_{4} \mathrm{O}_{7}(1-5)\right.$ $\left.\mathrm{H}_{2} \mathrm{O}\right]$, colemanite $\left[\mathrm{CaB}_{3} \mathrm{O}_{4}(\mathrm{OH})_{3} \mathrm{H}_{2} \mathrm{O}\right]$, boron oxide $\left[\mathrm{B}_{2} \mathrm{O}_{3}\right]$, borax decahydrate $\left[\mathrm{Na}_{2} \mathrm{~B}_{4} \mathrm{O}_{7} 10 \mathrm{H}_{2} \mathrm{O}\right]$, disodium octaborate tetrahydrate $\left[\mathrm{Na}_{2} \mathrm{~B}_{8} \mathrm{O}_{13} 4 \mathrm{H}_{2} \mathrm{O}\right]$ and boric acid $\left[\mathrm{H}_{3} \mathrm{BO}_{3}\right]$. Chemical pretreatments were made for 0,$5 ; 1$ and $2 \%(\mathrm{w} / \mathrm{v})$ concentrations and $10 \%(\mathrm{w} / \mathrm{v})$ solid loading. The pretreatment temperature was $121^{\circ} \mathrm{C}(15 \mathrm{psi})$. Pretreatment was made for both 60 and $90 \mathrm{~min}$. Chemically pretreated materials were filtrated and the solid parts were stored in sealed plastic bags at $4{ }^{\circ} \mathrm{C}$. The yield, acid in/ soluble lignin and sugar contents were determined in the solid materials and the optimum conditions for chemical pretreatments were determined regarding the ratio of glucan and lignin solubilization. In this study, samples accepted as optimum were further enzymatically hydrolyzed.

\section{Enzymatic hydrolysis}

The samples were hydrolyzed using commercial enzyme mixtures $(50 \% \mathrm{v} / \mathrm{v})$ and the accessibility of the samples for enzymatic conversion was examined. Celluclast $1,5 \mathrm{~L}$; generating the major cellulolytic activities (dosage $10 \mathrm{FPU} \mathrm{g}^{-1} \mathrm{dw}$ ) was supplemented with a beta-glucosidase of Novozym 188 (500 nkat $\mathrm{g}^{-1} \mathrm{dw}$ ) (Novozymes, Bagsvaerd, Denmark). The dry matter consistency in hydrolysis was $2 \%$. The experiments, in three replicates, were carried out in a volume of $50 \mathrm{ml}$ in $50 \mathrm{mM}$ Na-citrate buffer at $\mathrm{pH} 5$. In addition, $\mathrm{NaN}_{3}(0,02 \%)$ was added to prevent contamination during hydrolysis. The temperature was $50{ }^{\circ} \mathrm{C}$ and the shaking speed $100 \mathrm{rpm}$ in the incubator (Biosan Environmental Shaker-Incubator ES-20). Samples $(1,5 \mathrm{ml})$ were taken at the beginning $(0)$ and at 6, 24, 48 and 72 $\mathrm{h}$ of incubation. Next, the samples were first put into boiling water for $10 \mathrm{~min}$ to stop the enzymatic activity and then centrifuged at $10000 \mathrm{rpm}$ for $5 \mathrm{~min}$. The reducing sugars were determined from the supernatant and the results were expressed as percentage of the theoretical hydrolysis yield (formed sugars from theoretical sugars, i.e. polymeric carbohydrates calculated as monosaccharides) and as percentage of formed sugars from the whole dry matter of the hydrolyzed raw material.

\section{Analytical methods}

The yield of the samples was determined by gravimetric measurements. The extractives (Tappi T 204 om-88) and ash (Tappi T 211 om-85) contents of the samples were determined. The sugar and lignin contents of the samples were determined according to the Laboratory Analytical Procedures (LAP) from the NREL (Sluiter et al. 2004). The sugar contents were determined by utilizing the HPLC (Agilent 1200) system equipped with Shodex SP0810 column (mobile phase: HPLC grade water- 0,2 $\mu \mathrm{m}$ filtered and degassed, injection volume: $20 \mu \mathrm{L}$, flow rate: $0,6 \mathrm{ml} / \mathrm{min}$, column temperature: 80 ${ }^{\circ} \mathrm{C}$ ) and the refractive index detector. The acid-insoluble lignin was obtained by weighing the solid samples. The acid-soluble lignin was analyzed at the adsorption of $320 \mathrm{~nm}$ against blank deionized water. The percentage of solids recovered was calculated on an oven dry basis as follows:

The percentage of solids recovered $=\frac{W_{2}}{W_{1}} \times 100$

where $\mathrm{W}_{1}$ is the dry weight of the sample before pretreatment $(\mathrm{g})$ and $\mathrm{W}_{2}$ is the dry weight of the treated sample $(\mathrm{g})$.

The reduction in lignin was calculated according to the initial dry weight of lignin in the untreated material (LU) and the dry weight of lignin in the remaining solids after treatment (LP). The percentage of lignin reduction was calculated using the following equation: 
The percentage of lignin reduction $=\frac{L U-L P}{L U} \times 100$

In addition, the solubilization of glucan, xylan, galactan and mannan+arabinan in the pretreated samples was calculated in the same manner by substituting the appropriate percentage for glucan, xylan, galactan and mannan+arabinan.

In enzymatic hydrolysis, the reducing sugar content in the hydrolyzates was detected by the DNS method (Liu et al. 2011) and calculated by the equation:

$$
R S Y=\frac{m_{R S}}{m_{T}}=\frac{n C V}{m_{0}(1-\omega)} \times 100 \%
$$

where RSY is the reducing sugar yield (\%), $\mathrm{m}_{\mathrm{RS}}$ is the content of reducing sugar $(\mathrm{g}), \mathrm{m}_{\mathrm{T}}$ is the substrate mass $(\mathrm{g}), \mathrm{m}_{0}$ is the substrate weighted material $(\mathrm{g}), \omega$ is the moisture content $(\%), \mathrm{C}$ is the concentration of the reducing sugar $\left(\mathrm{g} \mathrm{L}^{-1}\right), \mathrm{V}$ is the total volume of hydrolyzate $(\mathrm{L})$ and $\mathrm{n}$ is the dilution time.

\section{RESULTS AND DISCUSSION}

\section{Characterization of sunflower stalks}

The composition (\% o.d. stalks) of the sunflower stalks used in this study consisted mainly of glucose, at $32,8 \%( \pm 0,40)$. The other sugars of xylose, galactose and mannose+arabinose were $16,7 \%$ $( \pm 0,12) ; 1,44 \%( \pm 0,22)$ and $1,89 \%( \pm 0,12)$; respectively. The total lignin (acid insoluble + acid soluble), extractives and ash content were $16,6 \%( \pm 0,45) ; 15,3 \%( \pm 0,14)$ and $7,10 \%( \pm 0,85)$; respectively.

The composition of sunflower stalks as reported earlier in the literature (Akpinar et al. 2011, López et al. 2010, Antonopoulou et al. 2015) revealed similar results. The only observed difference was the lignin content, and the lower lignin content in this study may be attributed to the differences in plant variety, climate, water availability, as well as other factors.

\section{Effect of chemical pretreatments}

The stalks were pretreated with chemicals and the recovered solids are shown in Table 1. Chemical pretreatments lowered the yields, and this could mainly be explained by the removal of lignin, hemicellulose and other soluble materials from the structure. Stalks treated with $2 \% \mathrm{CaB}_{3} \mathrm{O}_{4}(\mathrm{OH})_{3} \mathrm{H}_{2} \mathrm{O}$ and $\mathrm{NaOH}$ for 90 min treatment times resulted in the highest $(93,3 \%$ o.d. stalk) and the lowest $(64,8$ $\%$ o.d. stalk) solid recoveries, respectively. The different pretreatment chemical factors (8), chemical concentrations (3) and pretreatment times (2) and their interactions on glucan, xylan, galactan, mannan+arabinan and lignin are shown in Tables 2 and 3. 
Table 1. Solids recovery after pretreatments.

\begin{tabular}{|c|c|c|c|c|c|c|c|c|}
\hline \multirow{2}{*}{$\begin{array}{c}\text { Time (min); } \\
\begin{array}{c}\text { Concentration } \\
(\%)\end{array}\end{array}$} & \multicolumn{7}{|c|}{ Solids recovered after chemical pretreatments (\%) a $^{\mathrm{a}, \mathrm{b}}$} \\
\cline { 2 - 9 } & $\mathrm{NaOH}$ & $\mathrm{NaBH}_{4}$ & $\begin{array}{c}\mathrm{Na}_{2} \mathrm{~B}_{4} \mathrm{O}_{7}(1-5) \\
\mathrm{H}_{2} \mathrm{O}\end{array}$ & $\begin{array}{c}\mathrm{CaB}_{3} \mathrm{O}_{4}(\mathrm{OH})_{3} \\
\mathrm{H}_{2} \mathrm{O}\end{array}$ & $\mathrm{B}_{2} \mathrm{O}_{3}$ & $\begin{array}{c}\mathrm{Na}_{2} \mathrm{~B}_{4} \mathrm{O}_{7} \\
10 \mathrm{H}_{2} \mathrm{O}\end{array}$ & $\begin{array}{c}\mathrm{Na}_{2} \mathrm{~B}_{8} \mathrm{O}_{13} \\
4 \mathrm{H}_{2} \mathrm{O}\end{array}$ & $\mathrm{H}_{3} \mathrm{BO}_{3}$ \\
\hline $60 ; 0,5$ & $85,8 \pm 0,33$ & $86,8 \pm 0,23$ & $86,9 \pm 0,38$ & $87,4 \pm 0,18$ & $87,2 \pm 0,47$ & $88,5 \pm 0,58$ & $90,8 \pm 0,13$ & $85,4 \pm 0,27$ \\
\hline $60 ; 1$ & $84,0 \pm 0,37$ & $86,6 \pm 0,17$ & $87,2 \pm 0,48$ & $90,3 \pm 1,07$ & $87,2 \pm 0,65$ & $85,9 \pm 0,30$ & $89,2 \pm 0,45$ & $85,3 \pm 0,29$ \\
\hline $60 ; 2$ & $65,2 \pm 0,02$ & $83,8 \pm 0,35$ & $86,7 \pm 0,73$ & $90,8 \pm 0,33$ & $87,9 \pm 0,33$ & $88,1 \pm 0,22$ & $88,9 \pm 0,15$ & $86,4 \pm 0,36$ \\
\hline $90 ; 0,5$ & $83,9 \pm 0,21$ & $86,4 \pm 0,12$ & $87,1 \pm 0,41$ & $90,4 \pm 0,48$ & $85,8 \pm 0,51$ & $88,1 \pm 0,11$ & $88,6 \pm 1,01$ & $88,8 \pm 0,51$ \\
\hline $90 ; 1$ & $81,9 \pm 0,37$ & $86,0 \pm 0,35$ & $88,3 \pm 0,21$ & $91,0 \pm 0,17$ & $85,9 \pm 0,42$ & $86,2 \pm 097$ & $84,6 \pm 0,67$ & $90,5 \pm 0,19$ \\
\hline $90 ; 2$ & $64,8 \pm 0,32$ & $87,8 \pm 0,19$ & $84,4 \pm 0,16$ & $93,3 \pm 0,38$ & $86,8 \pm 0,24$ & $87,8 \pm 0,09$ & $89,5 \pm 0,56$ & $89,6 \pm 0,33$ \\
\hline
\end{tabular}
${ }^{\mathrm{b}}$ Data are averages of three replicates.

Table 2. The effects of chemicals, concentrations and time on glucan, xylan, galactan, mannan+arabinan and lignin (Duncan and $\mathrm{T}$ test).

\begin{tabular}{|clccccc|}
\hline Factor & Treatment & Glucan, \% & Xylan, \% & Galactan, \% & Mannan+Arabinan, \% & Lignin, \% \\
\hline \multirow{6}{*}{ Chemical } & $\mathrm{NaOH}$ & $27,6(\mathrm{ab})$ & $13,6(\mathrm{~b})$ & $0,33(\mathrm{~b})$ & $1,02(\mathrm{a})$ & $18,7(\mathrm{e})$ \\
& $\mathrm{NaBH}_{4}$ & $33,9(\mathrm{c})$ & $17,3(\mathrm{e})$ & $0,50(\mathrm{c})$ & $1,04(\mathrm{ab})$ & $15,5(\mathrm{a})$ \\
& $\mathrm{Na}_{2} \mathrm{~B}_{4} \mathrm{O}_{7}(1-5) \mathrm{H}_{2} \mathrm{O}$ & $27,4(\mathrm{a})$ & $11,4(\mathrm{a})$ & $0,26(\mathrm{ab})$ & $1,38(\mathrm{c})$ & $17,8(\mathrm{de})$ \\
& $\mathrm{CaB}_{3} \mathrm{O}_{4}(\mathrm{OH})_{3} \mathrm{H}_{2} \mathrm{O}$ & $27,7(\mathrm{ab})$ & $14,9(\mathrm{c})$ & $0,29(\mathrm{ab})$ & $1,43(\mathrm{c})$ & $16,1(\mathrm{ab})$ \\
& $\mathrm{B}_{2} \mathrm{O}_{3}$ & $28,8(\mathrm{~b})$ & $16,3(\mathrm{de})$ & $0,31(\mathrm{ab})$ & $1,54(\mathrm{c})$ & $16,5(\mathrm{abc})$ \\
& $\mathrm{Na}_{2} \mathrm{~B}_{4} \mathrm{O}_{7} 10 \mathrm{H}_{2} \mathrm{O}$ & $27,8(\mathrm{ab})$ & $16,1(\mathrm{~d})$ & $0,29(\mathrm{ab})$ & $1,25(\mathrm{abc})$ & $17,1(\mathrm{bcd})$ \\
& $\mathrm{Na}_{2} \mathrm{~B}_{8} \mathrm{O}_{13} 4 \mathrm{H}_{2} \mathrm{O}$ & $29,0(\mathrm{~b})$ & $15,9(\mathrm{~d})$ & $0,17(\mathrm{a})$ & $1,25(\mathrm{abc})$ & $16,9(\mathrm{bcd})$ \\
& $\mathrm{H}_{3} \mathrm{BO}_{3}$ & $27,6(\mathrm{ab})$ & $14,0(\mathrm{bc})$ & $0,30(\mathrm{ab})$ & $1,33(\mathrm{bc})$ & $17,3(\mathrm{~cd})$ \\
\hline \multirow{5}{*}{ Concentration $)$} & $29,2(\mathrm{a})$ & $15,5(\mathrm{~b})$ & $0,42(\mathrm{a})$ & $1,45(\mathrm{a})$ & $17,6(\mathrm{a})$ \\
& $0,5 \%$ & $28,5(\mathrm{a})$ & $14,8(\mathrm{a})$ & $0,32(\mathrm{~b})$ & $1,39(\mathrm{a})$ & $16,8(\mathrm{~b})$ \\
& $1 \%$ & $28,5(\mathrm{a})$ & $14,6(\mathrm{a})$ & $0,18(\mathrm{c})$ & $1,00(\mathrm{~b})$ & $16,5(\mathrm{~b})$ \\
\hline \multirow{2}{*}{ Time } & $2 \%$ & $30,5(\mathrm{a})$ & $16,0(\mathrm{a})$ & $0,29(\mathrm{a})$ & $1,44(\mathrm{a})$ & $17,5(\mathrm{a})$ \\
& $60 \mathrm{~min}$ & $26,9(\mathrm{a})$ & $13,9(\mathrm{~b})$ & $0,32(\mathrm{a})$ & $1,12(\mathrm{~b})$ & $16,5(\mathrm{a})$ \\
\hline
\end{tabular}

Means within each column and factor followed by the same letter are not significantly different by Duncan test $(\mathrm{p}<0,05)$ for chemicals and concentrations.

Means within each column and factor followed by the same letter are not significantly different by T test $(\mathrm{p}<0,05)$ for time. 
Table 3. The interactions of chemicals, time and concentrations on glucan, xylan, galactan, mannan+arabinan and lignin (ANOVA).

\begin{tabular}{|c|c|c|c|c|c|c|}
\hline Source & & $\begin{array}{c}\text { Type III Sum of } \\
\text { Squares }\end{array}$ & df & Mean Square & $\mathrm{F}$ & Sig. \\
\hline \multirow{7}{*}{ Glucan } & Chemical & 402,2 & 7 & 57,5 & 25,2 & * \\
\hline & Concentration & 11,0 & 2 & 5,52 & 2,42 & $* *$ \\
\hline & Time & 309,6 & 1 & 309,6 & 135,6 & $*$ \\
\hline & Chemical $*$ Concentration & 136,3 & 14 & 9,74 & 4,27 & $*$ \\
\hline & Chemical $*$ Time & 583,6 & 7 & 83,4 & 36,5 & $*$ \\
\hline & Concentration $*$ Time & 1,45 & 2 & 0,73 & 0,32 & NS \\
\hline & Chemical $*$ Concentration $*$ Time & 9,61 & 14 & 0,69 & 0,30 & NS \\
\hline \multirow{7}{*}{ Xylan } & Chemical & 296,4 & 7 & 42,3 & 29,7 & * \\
\hline & Concentration & 14,8 & 2 & 7,40 & 5,20 & ** \\
\hline & Time & 107,2 & 1 & 107,2 & 75,3 & $*$ \\
\hline & Chemical $*$ Concentration & 54,6 & 14 & 3,90 & 2,74 & ** \\
\hline & Chemical * Time & 105,6 & 7 & 15,1 & 10,6 & $*$ \\
\hline & Concentration $*$ Time & 1,38 & 2 & 0,69 & 0,48 & NS \\
\hline & Chemical $*$ Concentration $*$ Time & 3,99 & 14 & 0,29 & 0,20 & NS \\
\hline \multirow{7}{*}{ Galactan } & Chemical & 0,72 & 7 & 0,10 & 3,69 & ** \\
\hline & Concentration & 0,89 & 2 & 0,44 & 16,0 & $*$ \\
\hline & Time & 0,34 & 1 & 0,03 & 1,22 & NS \\
\hline & Chemical $*$ Concentration & 0,49 & 14 & 0,04 & 1,26 & NS \\
\hline & Chemical $*$ Time & 0,80 & 7 & 0,12 & 4,14 & ** \\
\hline & Concentration * Time & 0,01 & 2 & 0,01 & 0,04 & NS \\
\hline & Chemical $*$ Concentration $*$ Time & 0,49 & 14 & 0,04 & 1,27 & NS \\
\hline \multirow{7}{*}{$\begin{array}{c}\text { Mannan } \\
+ \\
\text { Arabinan }\end{array}$} & Chemical & 2,79 & 7 & 0,40 & 3,32 & ** \\
\hline & Concentration & 3,74 & 2 & 1,87 & 15,6 & * \\
\hline & Time & 2,38 & 1 & 2,38 & 19,8 & * \\
\hline & Chemical * Concentration & 5,10 & 14 & 0,37 & 3,04 & ** \\
\hline & Chemical $*$ Time & 3,24 & 7 & 0,46 & 3,87 & ** \\
\hline & Concentration $*$ Time & 0,06 & 2 & 0,03 & 0,26 & NS \\
\hline & Chemical $*$ Concentration $*$ Time & 1,71 & 14 & 0,12 & 1,02 & NS \\
\hline \multirow{7}{*}{ Lignin } & Chemical & 84,0 & 7 & 12,0 & 7,63 & * \\
\hline & Concentration & 21,8 & 2 & 10,9 & 6,94 & ** \\
\hline & Time & 26,9 & 1 & 26,9 & 17,1 & $*$ \\
\hline & Chemical $*$ Concentration & 45,4 & 14 & 3,24 & 2,06 & $* * *$ \\
\hline & Chemical $*$ Time & 7,99 & 7 & 1,14 & 0,73 & NS \\
\hline & Concentration $*$ Time & 0,74 & 2 & 0,37 & 0,24 & NS \\
\hline & Chemical $*$ Concentration $*$ Time & 5,10 & 14 & 0,37 & 0,23 & NS \\
\hline
\end{tabular}

$\mathrm{P}=$ Significance level.

NS = Non significant for ANOVA.

* Significant at 0,001 for ANOVA.

** Significant at 0,01 for ANOVA.

*** Significant at 0,05 for ANOVA.

\section{Effects of chemical pretreatment on glucan content}

Using $\mathrm{NaOH}$ as the pretreatment agent degrades the H-bonds in cellulose and hemicellulose, and in addition breaks ester linkages between lignin and xylan (Sun et al. 2005). This consequently results in swelling that causes hemicelluloses and lignin dissolution (Chen and Sharma-Shivappa 2007). The $\mathrm{NaOH}$ pretreatment showed that higher application times and alkali concentrations dissolved more material from the structure and resulted in a lower yield (Table 1). The glucan content of the $\mathrm{NaOH}$ pretreated stalks ranged from $17,7 \%(0,5 \%$ conc., $90 \mathrm{~min})$ to $40,6 \%$ (2\% conc., $60 \mathrm{~min})$. On the other 
hand, dissolved glucan was found to be between 11,3\% (0,5\% conc., $60 \mathrm{~min})$ and 55,4 \% (2\% conc., $90 \mathrm{~min}$ ) (Figure 1a). Results showed that, compared to alkali concentration, residency time was more effective in glucan solubilization. Silverstein et al. (2007) reported nearly $21 \%$ glucan solubilization for cotton stalks when treated with $2 \% \mathrm{NaOH}$ at $121{ }^{\circ} \mathrm{C}$ for $60 \mathrm{~min}$. On the other hand, Monlau et al. (2013) observed a much lower $(<8 \%)$ glucan solubilization when sunflower stalks were pretreated with $4 \% \mathrm{NaOH}\left(55^{\circ} \mathrm{C}\right.$ for $24 \mathrm{~h}$ or $170{ }^{\circ} \mathrm{C}$ for $\left.1 \mathrm{~h}\right)$. The unpredicted glucan dissolution in this study could be due to the pretreatment conditions, raw material characteristics (region, crop maturity, harvest times, plant parts), etc.

The pulping additive $\mathrm{NaBH}_{4}$ is conventionally used to improve the pulping selectivity of the kraft method. The chemical acts as a catalyst and results in selective delignification (Copur and Tozluoglu 2007). It improves the pulping yield by preventing carbohydrate degradation (Copur et al. 2012). On the other hand, there is limited knowledge available on of the use of $\mathrm{NaBH}_{4}$ as a pretreatment chemical in bioethanol production. The effects of $\mathrm{NaBH}_{4}$ used as a pretreatment chemical for wheat straw, corn stalks and hazelnut husks have been studied (Copur et al. 2012, Copur et al. 2013a, Copur et al. 2013b) and it has been shown to be as effective as $\mathrm{NaOH}$ for chemical pretreatment. The glucan solubilization during $\mathrm{NaBH}_{4}$ pretreatment is presented in Figure $1 \mathrm{~b}$ and the solids recovered after pretreatment are given in Table 1. Results showed that higher residency times and treatment concentrations diminished the yield. The glucan content of $\mathrm{NaBH}_{4}$ pretreated samples ranged from $32,3 \%\left(2 \% \mathrm{NaBH}_{4}, 90 \mathrm{~min}\right)$ to $35,3 \%\left(0,5 \% \mathrm{NaBH}_{4}, 60 \mathrm{~min}\right)$ (o.d. stalk) and the glucan solubilization was found to be as high as $13,5 \%$ (2\% $\mathrm{NaBH}_{4}, 90 \mathrm{~min}$ ) (Figure 1b). Copur et al. (2012 and 2013b) reported 7,27\% and 31,6\% glucan solubilization, respectively, when wheat straw and hazelnut husks were pretreated with $2 \%$ and $4 \% \mathrm{NaBH}_{4}$ at $121{ }^{\circ} \mathrm{C}$ for $30 \mathrm{~min}$.
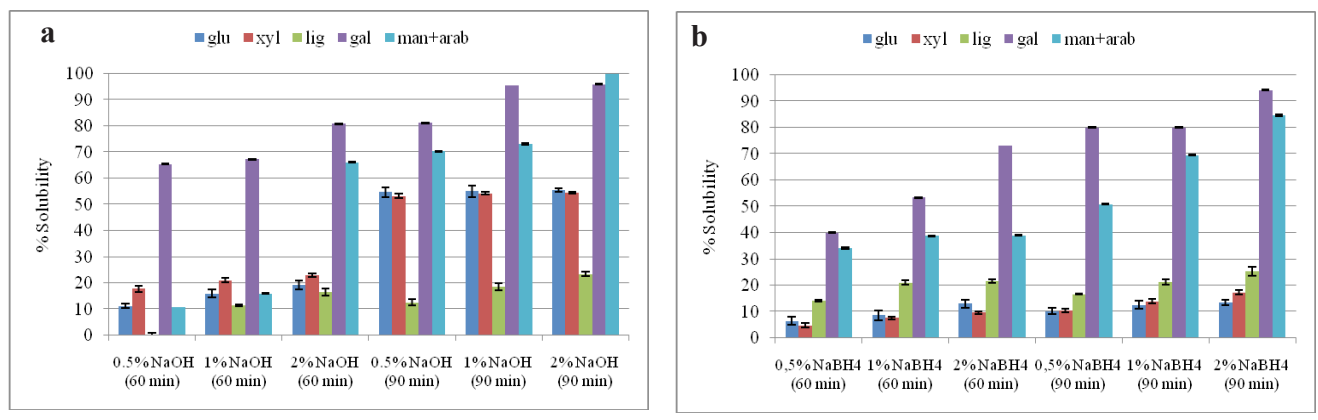

Figure 1. Solubilization of glucan, xylan, galactan, mannan+arabinan and lignin in (a) $\mathrm{NaOH}$ and (b) $\mathrm{NaBH}_{4}$ pretreated samples as a function of residence time and concentration.

The glucan content of the $\mathrm{Na}_{2} \mathrm{~B}_{4} \mathrm{O}_{7}(1-5) \mathrm{H}_{2} \mathrm{O}, \quad \mathrm{CaB}_{3} \mathrm{O}_{4}(\mathrm{OH})_{3} \mathrm{H}_{2} \mathrm{O}, \mathrm{B}_{2} \mathrm{O}_{3} \quad \mathrm{Na}_{2} \mathrm{~B}_{4} \mathrm{O}_{7} 10 \mathrm{H}_{2} \mathrm{O}$, $\mathrm{Na}_{2} \mathrm{~B}_{8} \mathrm{O}_{13} 4 \mathrm{H}_{2} \mathrm{O}$ and $\mathrm{H}_{3} \mathrm{BO}_{3}$ pretreated samples ranged from $24,7 \%$ (1\% conc., 90 min) to $30,7 \%(0,5$ $\%$ conc., $60 \mathrm{~min}$ ); $26,3 \%$ ( $2 \%$ conc., $90 \mathrm{~min}$ ) to $29,7 \%$ (0,5\% conc., $60 \mathrm{~min}), 27 \%$ (2\% conc., 90 $\mathrm{min}$ ) to $30,6 \%$ (0,5 \% conc., $60 \mathrm{~min}) ; 25,5 \%$ ( $2 \%$ conc., $90 \mathrm{~min})$ to $29 \%(0,5 \%$ conc., $60 \mathrm{~min}), 27$ $\%$ (2\% conc., $90 \mathrm{~min})$ to $29,9 \%$ (0,5\% conc., $60 \mathrm{~min})$ and $26 \%$ (2\% conc., $90 \mathrm{~min})$ to $29 \%(0,5$ $\%$ conc., $60 \mathrm{~min}$ ), respectively. The highest glucan solubilization was found to be 33,6\% when the stalks were pretreated with $\mathrm{Na}_{2} \mathrm{~B}_{4} \mathrm{O}_{7}(1-5) \mathrm{H}_{2} \mathrm{O}(2 \%$ conc., $90 \mathrm{~min})$, while the lowest was $25,9 \%$ with $\mathrm{CaB}_{3} \mathrm{O}_{4}(\mathrm{OH})_{3} \mathrm{H}_{2} \mathrm{O}(1 \%$ conc., $90 \mathrm{~min})$ (Figure 2a-f). 

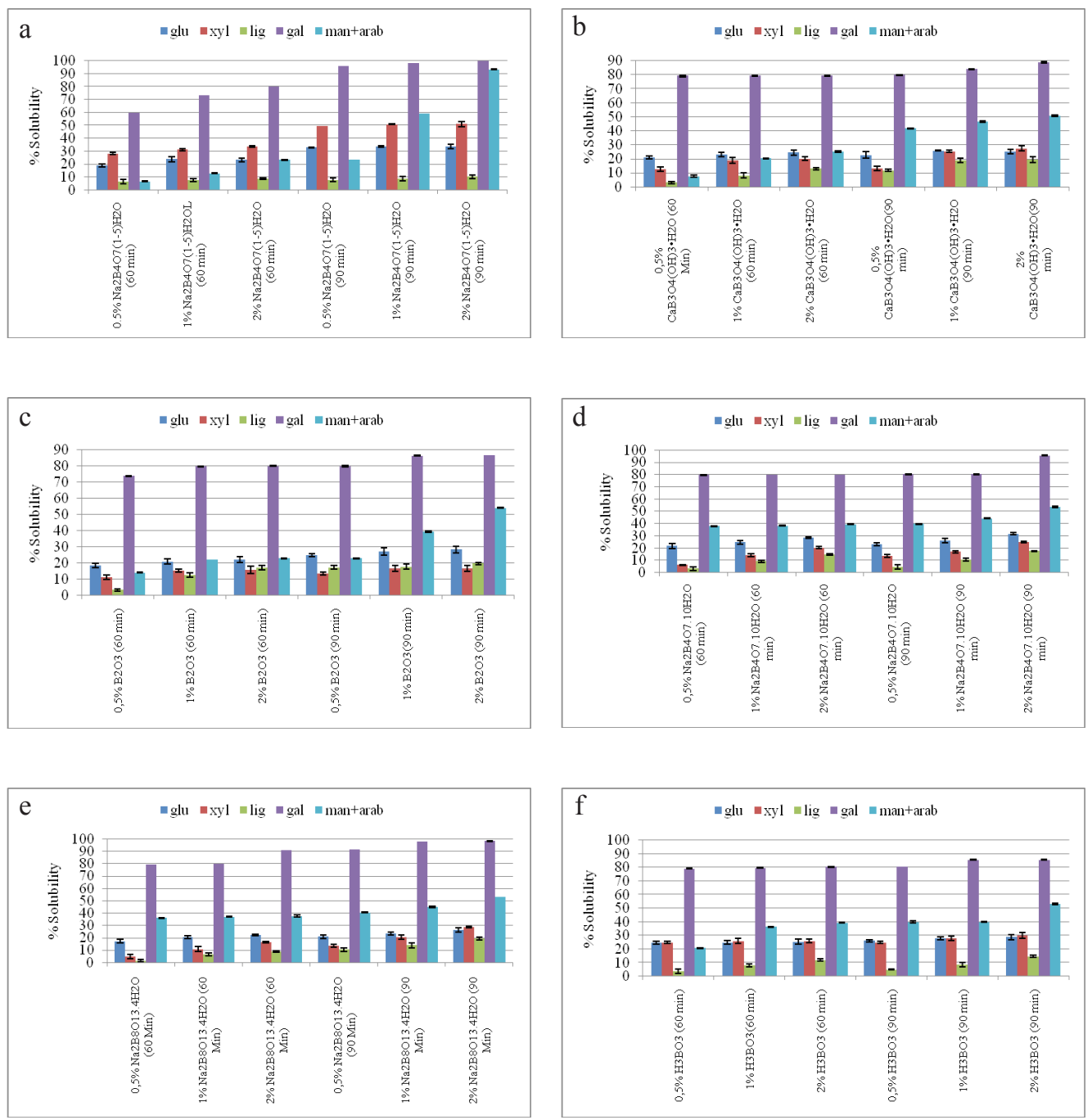

Figure 2. Solubilization of pretreated samples as a function of residence time and concentration: glucan, xylan, galactan, mannan+arabinan and lignin in (a) $\mathrm{Na}_{2} \mathrm{~B}_{4} \mathrm{O}_{7}(1-5) \mathrm{H}_{2} \mathrm{O}$, (b) $\mathrm{CaB}_{3} \mathrm{O}_{4}(\mathrm{OH})_{3} \mathrm{H}_{2} \mathrm{O}$, (c) $\mathrm{B}_{2} \mathrm{O}_{3}$, (d) $\mathrm{Na}_{2} \mathrm{~B}_{4} \mathrm{O}_{7} 10 \mathrm{H}_{2} \mathrm{O}$, (e) $\mathrm{Na}_{2} \mathrm{~B}_{8} \mathrm{O}_{13} 4 \mathrm{H}_{2} \mathrm{O}$ and (f) $\mathrm{H}_{3} \mathrm{BO}_{3}$.

\section{Effects of chemical pretreatment on xylan content}

The xylan content of $\mathrm{NaOH}$ pretreated solids ranged from $9,30 \%(0,5 \%$ conc., $90 \mathrm{~min})$ to 19,7 $\%$ ( $2 \%$ conc., $60 \mathrm{~min}$ ). Results (Figure 1a) indicated that the pretreatments removed xylan from the structure, and harsher pretreatment conditions dissolved more xylan. Xylan, which is an amorphous, low molecular weight, heterogeneous and branched polysaccharide, is more susceptible to alkaline attacks. The $\mathrm{NaOH}$ pretreatment dissolved from $17,8 \%$ (0,5\% conc., $60 \mathrm{~min})$ to $54,6 \%$ (2\% conc., $90 \mathrm{~min}$ ) of the xylan. These results were comparable to the findings of Antonopoulou et al. (2015), who achieved xylan removal of 30,2; 34,8 and 44,9\% with sunflower stalks pretreated, respectively, with 2, 10 and $20 \% \mathrm{NaOH}$ at $80{ }^{\circ} \mathrm{C}$ for $24 \mathrm{~h}$. In addition, Monlau et al. (2013) reported 26 and $58 \%$ xylan removal when sunflower stalks were pretreated with $4 \% \mathrm{NaOH}$ at 55 and $170{ }^{\circ} \mathrm{C}$, respectively, for $24 \mathrm{~h}$, while Wang et al. (2010) obtained 60,5\% xylan solubilization for bermuda grass $(3 \% \mathrm{NaOH}$, $121{ }^{\circ} \mathrm{C}, 90 \mathrm{~min}$ ). On the other hand, slightly lower xylan solubility was reported by Chen and SharmaShivappa (2007) for barley straw (40\%), triticale straw (35\%) and wheat straw (35\%) when the 
materials were pretreated with $2 \% \mathrm{NaOH}$ at $121{ }^{\circ} \mathrm{C}$ for $60 \mathrm{~min}$.

When the $\mathrm{NaBH}_{4}$ pretreatment is take into account, the xylan content of the stalks ranged from $15,7 \%$ ( $2 \%$ conc., $90 \mathrm{~min})$ to $18,3 \%(0,5 \%$ conc., $60 \mathrm{~min})$, whereas xylan removal ranged from 4,88 $\%(0,5 \%$ conc., $60 \mathrm{~min})$ to $17,4 \%$ (2\% conc., $90 \mathrm{~min})$ (Figure 1b). Copur et al. (2012 and 2013b) reported almost $58,7 \%$ and $66,2 \%$ xylan solubilization for wheat straw and hazelnut husks when the materials were pretreated with $4 \% \mathrm{NaBH}_{4}$ at $121{ }^{\circ} \mathrm{C}$ for $90 \mathrm{~min}$ and $30 \mathrm{~min}$, respectively. The lower xylan solubility in the present study could be due to differing raw material characteristics.

On the other hand, the samples pretreated with $\mathrm{Na}_{2} \mathrm{~B}_{4} \mathrm{O}_{7}(1-5) \mathrm{H}_{2} \mathrm{O}, \mathrm{CaB}_{3} \mathrm{O}_{4}(\mathrm{OH})_{3} \mathrm{H}_{2} \mathrm{O}, \mathrm{B}_{2} \mathrm{O}_{3}$ $\mathrm{Na}_{2} \mathrm{~B}_{4} \mathrm{O}_{7} 10 \mathrm{H}_{2} \mathrm{O}, \mathrm{Na}_{2} \mathrm{~B}_{8} \mathrm{O}_{13} 4 \mathrm{H}_{2} \mathrm{O}$ and $\mathrm{H}_{3} \mathrm{BO}_{3}$ resulted in $9,33 \%$ (1\% conc., $\left.90 \mathrm{~min}\right)$ to $13,8 \%(0,5 \%$ conc., $60 \mathrm{~min}), 13 \%(2 \%$ conc., $90 \mathrm{~min})$ to $16,7 \%$ (0,5\% conc., $60 \mathrm{~min}), 16 \%$ ( $2 \%$ conc., $90 \mathrm{~min})$ to $17 \%$ ( $0,5 \%$ conc., $60 \mathrm{~min}) ; 14,3 \%$ (2\% conc., $90 \mathrm{~min})$ to $17,7 \%(0,5 \%$ conc., $60 \mathrm{~min}) ; 13,3 \%$ ( $2 \%$ conc., $90 \mathrm{~min})$ to $17,5 \%(0,5 \%$ conc., $60 \mathrm{~min})$ and $13 \%(2 \%$ conc., $90 \mathrm{~min})$ to $14,7 \%(0,5 \%$ conc., $60 \mathrm{~min}$ ) of xylan in the structure, respectively. These results indicated that $\mathrm{H}_{3} \mathrm{BO}_{3}$ removed a significant amount $(30,3 \%)$ of xylan from the structure when the stalks were pretreated with a $2 \%$ chemical concentration for 90 min (Figure 2a-f).

\section{Effects of chemical pretreatment on lignin content}

Lignin, a three-dimensional, complex aromatic polymer, surrounds the carbohydrates (cellulose and hemicellulose) in woody biomass (Fan et al. 1987). However, lignin limits the accessibility of hydrolytic enzymes to the carbohydrates and some of its decrease or removal is crucial in order to improve the digestibility. The $\mathrm{NaOH}$ pretreatment removed the lignin from the stalk structure. The amount of lignin in the solids after the $\mathrm{NaOH}$ pretreatment ranged from 16,5\% (1\% conc., $90 \mathrm{~min})$ to $21,5 \%$ ( $2 \%$ conc., $60 \mathrm{~min}$ ). An increased alkali concentration removed greater amounts of lignin, with the highest lignin removal in this study being $23,5 \%$ (2\% conc., 90 min) (Figure 1a).

Comparable lignin removal (20\%) was observed by Antonopoulou et al. (2015) while pretreating sunflower stalks with $2 \% \mathrm{NaOH}$ at $80{ }^{\circ} \mathrm{C}$ for $24 \mathrm{~h}$. In addition, Monlau et al. (2013), by pretreating sunflower stalks with $4 \% \mathrm{NaOH}$ at 55 and $170{ }^{\circ} \mathrm{C}$ for $24 \mathrm{~h}$. observed nearly the same lignin removal (22 and $36 \%$, respectively). Gaspar et al. (2005) and Wang et al. (2010) reported $95 \%$ lignin removal for corn fiber $\left(2,5 \%\right.$ conc., $\left.121^{\circ} \mathrm{C}, 60 \mathrm{~min}\right)$ and $86 \%$ removal for bermuda grass $(3 \%$ conc., 121 ${ }^{\circ} \mathrm{C}, 90 \mathrm{~min}$ ), respectively. The higher lignin removal (95\%) for corn stover reported by Varga et al. (2002) might be attributed to the higher $\mathrm{NaOH}$ concentration (10\%). In the present study, the $\mathrm{NaOH}$ concentration was limited to $2 \%$. The results indicated that lignin removal depends on pretreatment conditions and the characteristics of the raw material.

The lignin content of the $\mathrm{NaBH}_{4}$ treated samples ranged from $14,1 \%$ (2\% conc., $\left.90 \mathrm{~min}\right)$ to $16,6 \%$ (0,5 \% conc., $60 \mathrm{~min})$ and lignin removal ranged from $14,2 \%(0,5 \%$ conc., $60 \mathrm{~min})$ to 25,4 $\%$ (2\% conc., $90 \mathrm{~min}$ ) (Figure 1b). Copur et al. (2012 and 2013b) reported almost 58,4 and 49,1\% delignification, respectively, for wheat straw and hazelnut husks $\left(4 \% \mathrm{NaBH}_{4}, 121^{\circ} \mathrm{C}, 90 \mathrm{~min}\right)$. Similar lignin removal $(23,5 \%)$ was observed in this study when the sunflower stalks were pretreated with $2 \%$ $\mathrm{NaOH}$ for $90 \mathrm{~min}$. More lignin, as compared to xylan, was removed from the sunflower stalks treated with $\mathrm{NaBH}_{4}$. It is known that the removal of lignin is considerably important to improve enzymatic digestibility.

The lignin content of the samples treated with $\mathrm{Na}_{2} \mathrm{~B}_{4} \mathrm{O}_{7}(1-5) \mathrm{H}_{2} \mathrm{O}, \mathrm{CaB}_{3} \mathrm{O}_{4}(\mathrm{OH})_{3} \mathrm{H}_{2} \mathrm{O}, \mathrm{B}_{2} \mathrm{O}_{3}$ $\mathrm{Na}_{2} \mathrm{~B}_{4} \mathrm{O}_{7} 10 \mathrm{H}_{2} \mathrm{O}, \mathrm{Na}_{2} \mathrm{~B}_{8} \mathrm{O}_{13} 4 \mathrm{H}_{2} \mathrm{O}$ and $\mathrm{H}_{3} \mathrm{BO}_{3}$ ranged from $17,4 \%$ (1 \% conc., $\left.90 \mathrm{~min}\right)$ to $18,1 \%(0,5 \%$ conc., $60 \mathrm{~min}) ; 14,3 \%$ ( $2 \%$ conc., $90 \mathrm{~min})$ to $18,4 \%$ ( $0,5 \%$ conc., $60 \mathrm{~min}) ; 15,5 \%$ ( $2 \%$ conc., $90 \mathrm{~min})$ to $18,6 \%$ ( $0,5 \%$ conc., $60 \mathrm{~min}) ; 15,6 \%$ (2\% conc., $90 \mathrm{~min})$ to $18,2 \%$ ( $0,5 \%$ conc., $60 \mathrm{~min}), 15 \%$ (2 $\%$ conc., $90 \mathrm{~min})$ to $18 \%$ ( $0,5 \%$ conc., $60 \mathrm{~min})$ and $15,8 \%$ (2\% conc., $90 \mathrm{~min})$ to $18,7 \%(0,5 \%$ conc., $60 \mathrm{~min})$, respectively. The minimum (10,1\%) and maximum (19,8\%) lignin removal was found when stalks were treated with $\mathrm{Na}_{2} \mathrm{~B}_{4} \mathrm{O}_{7}(1-5) \mathrm{H}_{2} \mathrm{O}$ and $\mathrm{B}_{2} \mathrm{O}_{3}$, respectively $(2 \%$ conc., 90 min) (Figure 2a-f). 


\section{Optimum pretreatment application}

Results showed that, compared to $\mathrm{NaOH}$, all boron derivatives prevented peeling reactions and preserved more glucan in the structure. Among the chemicals used in pretreatments, $\mathrm{NaOH}$ removed the highest xylan and lignin from the structure. On the other hand, significant xylan removal was observed when the sunflower stalks were pretreated with $\mathrm{H}_{3} \mathrm{BO}_{3}$. It was found that $\mathrm{B}_{2} \mathrm{O}_{3}$ was as effective as $\mathrm{NaBH}_{4}$ and $\mathrm{NaOH}$ for selective lignin removal. Moreover, it is known (Copur et al. 2013a, 2013b) that effective enzymatic hydrolysis is possible when conjoint removal of xylan and lignin is in progress.

The optimum pretreatment conditions were determined based on the ratio of the glucan and lignin removal during pretreatment applications. The optimum ratios were 0,$80 ; 2,44 ; 0,37 ; 0,78 ; 0,78 ; 0,51$; 0,73 and 0,51 when the samples were pretreated with $2 \% \mathrm{NaOH}(60 \mathrm{~min}), 1 \% \mathrm{NaBH}_{4}(60 \mathrm{~min}), 2 \%$ $\mathrm{Na}_{2} \mathrm{~B}_{4} \mathrm{O}_{7}(1-5) \mathrm{H}_{2} \mathrm{O}(60 \mathrm{~min}), 2 \% \mathrm{CaB}_{3} \mathrm{O}_{4}(\mathrm{OH})_{3} \mathrm{H}_{2} \mathrm{O}(90 \mathrm{~min}), 2 \% \mathrm{~B}_{2} \mathrm{O}_{3}(60 \mathrm{~min}), 2 \% \mathrm{Na}_{2} \mathrm{~B}_{4} \mathrm{O}_{7} 10 \mathrm{H}_{2} \mathrm{O}$ $(60 \mathrm{~min}), 2 \% \mathrm{Na}_{2} \mathrm{~B}_{8} \mathrm{O}_{13} 4 \mathrm{H}_{2} \mathrm{O}(90 \mathrm{~min})$ and $2 \% \mathrm{H}_{3} \mathrm{BO}_{3}(90 \mathrm{~min})$, respectively. Results indicated that extremely selective delignification was possible when stalks were pretreated with $\mathrm{NaBH}_{4}$.

\section{Enzymatic hydrolysis}

In this study, the samples pretreated under optimum conditions were enzymatically hydrolyzed. The reducing sugar contents were $58,8 \pm 0,01 \% ; 73,3 \pm 0,01 \% ; 70,8 \pm 0,14 \% ; 66,9 \pm 0,01 \% ; 67,8 \pm 0,05$ $\% ; 68,6 \pm 0,01 \% ; 67,3 \pm 0,07 \% ; 62,4 \pm 0,01 \%$ and $72,2 \pm 0,01 \%$ for the untreated and pretreated samples $\left(2 \% \mathrm{NaOH}, 60 \mathrm{~min} ; 1 \% \mathrm{NaBH}_{4}, 60\right.$ min; $2 \% \mathrm{Na}_{2} \mathrm{~B}_{4} \mathrm{O}_{7}(1-5) \mathrm{H}_{2} \mathrm{O} ; 60 \mathrm{~min} ; 2 \% \mathrm{CaB}_{3} \mathrm{O}_{4}(\mathrm{OH})_{3} \mathrm{H}_{2} \mathrm{O}, 90$ $\min ; 2 \% \mathrm{~B}_{2} \mathrm{O}_{3}, 60 \mathrm{~min} ; 2 \% \mathrm{Na}_{2} \mathrm{~B}_{4} \mathrm{O}_{7} 10 \mathrm{H}_{2} \mathrm{O}, 60 \mathrm{~min} ; 2 \% \mathrm{Na}_{2} \mathrm{~B}_{8} \mathrm{O}_{13} 4 \mathrm{H}_{2} \mathrm{O}, 90 \mathrm{~min}$; and $2 \% \mathrm{H}_{3} \mathrm{BO}_{3}, 90$ $\mathrm{min})$, respectively. The reducing sugars observed for samples of $2 \% \mathrm{~B}_{2} \mathrm{O}_{3}(60 \mathrm{~min}), 2 \% \mathrm{H}_{3} \mathrm{BO}_{3}(90$ $\mathrm{min}), 1 \% \mathrm{NaBH}_{4}(60 \mathrm{~min})$ and $2 \% \mathrm{NaOH}(60 \mathrm{~min})$ were nearly similar. This finding indicated that the abovementioned boron derivatives as well as $\mathrm{NaOH}$ could improve the enzymatic digestibility of the pretreated samples.

The effects of enzymatic hydrolysis and incubation periods on the hydrolysis of sunflower stalks were examined and the results are presented in Figure 3. The saccharification rate up to $24 \mathrm{~h}$ was higher, and then, continuing to $72 \mathrm{~h}$, the rate slowed down. This behavior might be due to the diminishing enzyme adsorption during saccharification, the changing of the cellulose structure to a less digestible form and the inhibiting enzymes resulting from the products of hydrolysis (Lee and Fan 1982). The slow rate of saccharification after $72 \mathrm{~h}$ has also been reported earlier (Sreenath et al. 1999).

The untreated samples gave a hydrolysis yield of $26,6 \%$ when enzymatic application progressed for $72 \mathrm{~h}$. This value was significantly higher compared to that of $18 \%$ observed by Ruiz et al. (2008). The only difference between the studies was in the substrate concentration, which was $10 \%(\mathrm{w} / \mathrm{v})$ compared to the $2 \%(\mathrm{w} / \mathrm{v})$ employed in this study. It is known that a decrease in the substrate concentration accelerates the rate of hydrolysis. Substrate concentrations of over $0,05-0,075 \mathrm{~g} / \mathrm{ml}$ may cause substrate inhibition (Soto et al. 1994). In addition, enzymatic hydrolysis may be decreased as a result of stirring problems, aqueous movable phase reduction and end product inhibition (Sharma et al. 2002).

In this study, the $2 \% \mathrm{NaOH}(60 \mathrm{~min})$ pretreatment resulted in the highest enzymatic saccharification yield $(59,5 \%)$ among the samples. The boron derivatives gave slightly lower values $\left(1 \% \mathrm{NaBH}_{4}\right.$, $45 \% ; 2 \% \mathrm{~B}_{2} \mathrm{O}_{3}, 40,2 \%$; and $2 \% \mathrm{H}_{3} \mathrm{BO}_{3}, 36,7 \%$ ). Sharma et al. (2002) observed an enzymatic saccharification yield of $57,8 \%$ for steam exploded and chemically pretreated sunflower stalks. On the other hand, Ruiz et al. (2008 and 2013) obtained enzymatic hydrolysis yields of 67,8 and $65 \%$ of with steam exploded and 1,3\% sulfuric acid pretreated sunflower stalks, respectively. These variations in the enzymatic hydrolysis yield could be explained by the diverse process conditions applied in the studies.

It could be mentioned that enzymatic hydrolysis yield is a function of the lignin and xylan contents of the stalk. In this study, the $\mathrm{Na}_{2} \mathrm{~B}_{4} \mathrm{O}_{7}(1-5) \mathrm{H}_{2} \mathrm{O}$ pretreated sample had the highest lignin content $(17,7$ $\%$; however, the lowest lignin content was observed when the sample was pretreated with $\mathrm{NaBH}_{4}$ $(15,3 \%)$. Consequently, the $\mathrm{Na}_{2} \mathrm{~B}_{4} \mathrm{O}_{7}(1-5) \mathrm{H}_{2} \mathrm{O}$ pretreated sample had 1,16 times more lignin and an enzymatic yield 1,52 times lower compared to samples treated with $\mathrm{NaBH}_{4}$. 
In addition, regarding the xylan content of the samples, those pretreated with $\mathrm{Na}_{2} \mathrm{~B}_{4} \mathrm{O}_{7} 10 \mathrm{H}_{2} \mathrm{O}$ and $\mathrm{H}_{3} \mathrm{BO}_{3}$ had 15,1 and $13 \%$ xylan content, respectively. Therefore, the $\mathrm{Na}_{2} \mathrm{~B}_{4} \mathrm{O}_{7} 10 \mathrm{H}_{2} \mathrm{O}$ pretreated sample had 1,16 times more xylan in the structure compared to the $\mathrm{H}_{3} \mathrm{BO}_{3}$ pretreated sample, and consequently, $\mathrm{Na}_{2} \mathrm{~B}_{4} \mathrm{O}_{7} 10 \mathrm{H}_{2} \mathrm{O}$ gave an enzymatic yield that was 1,13 times lower. These results indicated that xylan as well as lignin removal had a significant effect on the enzymatic digestibility. Similar findings were reported earlier by Lu et al. (2002), and Yang and Wyman (2004), who concluded that lignin in the structure obstructed the hydrolysis and attributed this to the protein adsorption of lignin in aqueous solutions.
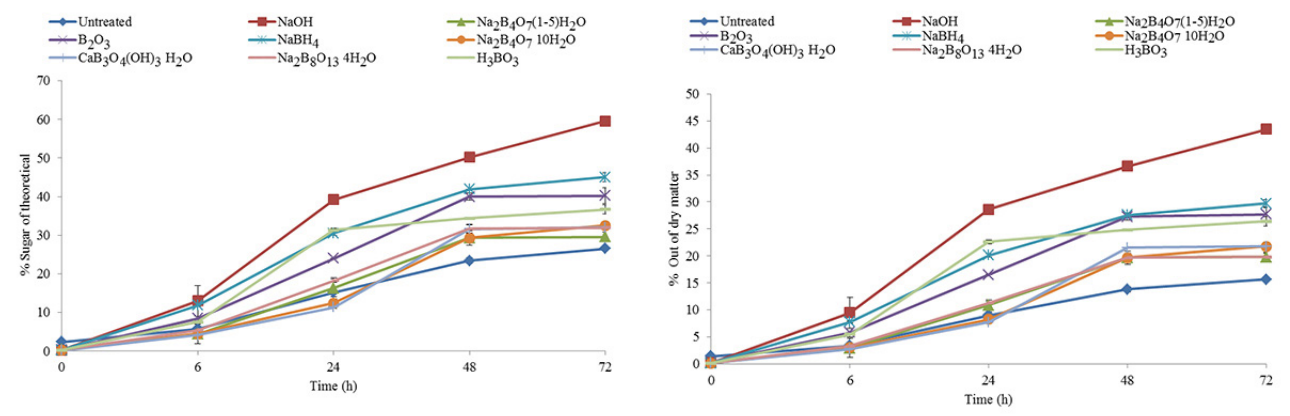

Figure 3. Enzymatic hydrolysis of pretreated sunflower stalks, expressed as $\%$ of total carbohydrates.

\section{CONCLUSIONS}

Sunflower stalks were treated with $\mathrm{NaOH}, \mathrm{NaBH}_{4}$ and the boron derivatives $\mathrm{Na}_{2} \mathrm{~B}_{4} \mathrm{O}_{7}(1-5) \mathrm{H}_{2} \mathrm{O}$, $\mathrm{CaB}_{3} \mathrm{O}_{4}(\mathrm{OH})_{3} \mathrm{H}_{2} \mathrm{O}, \mathrm{B}_{2} \mathrm{O}_{3}, \mathrm{Na}_{2} \mathrm{~B}_{4} \mathrm{O}_{7} 10 \mathrm{H}_{2} \mathrm{O}, \mathrm{Na}_{2} \mathrm{~B}_{8} \mathrm{O}_{13} 4 \mathrm{H}_{2} \mathrm{O}$ and $\mathrm{H}_{3} \mathrm{BO}_{3}$. Results showed that the boron derivatives prevented peeling reactions and preserved more glucan; however, the $\mathrm{NaOH}$ removed the highest amounts of xylan and lignin from the structure. The significant xylan removal observed with $\mathrm{H}_{3} \mathrm{BO}_{3}$ and $\mathrm{B}_{2} \mathrm{O}_{3}$ was as effective as $\mathrm{NaBH}_{4}$ and $\mathrm{NaOH}$ for selective lignin removal, although the highest enzymatic saccharification yield was $59,5 \%$ for the $2 \% \mathrm{NaOH}$ pretreated sample. In addition, some boron derivatives gave slightly lower yields $\left(1 \% \mathrm{NaBH}_{4}-45 \% ; 2 \% \mathrm{~B}_{2} \mathrm{O}_{3}-40,2 \%\right.$; and $2 \% \mathrm{H}_{3} \mathrm{BO}_{3}-36,7$ $\%$ ) compared to $\mathrm{NaOH}$. Although the price is disadvantage compared to $\mathrm{NaOH}$, the potential results of using of boron derivatives might be worth the cost.

\section{REFERENCES}

Akpinar, O.; Levent, O.; Sabanci, S.; Uysal, R. S.; Sapci, B. 2011. Optimization and comparison of dilute acid pretreatment of selected agricultural residues for recovery of xylose. BioRes 6(4):41034116.

Anonymous.2014a. T.R. Ministry of Customs and Trade-Year 2014 sunflower report <http:// koop.gtb.gov.tr/data/53319ccf487c8eb1e43d7298/2014\%20Ay\%C3\%A7i\%C3\%A7e\%C4\%9Fi\%20 Raporu.pdf.> [Accessed 12 May 2015].

Anonymous. 2014b. Sunflower and sunflower oil production, imports and problems $<$ http://www. zmo.org.tr/genel/bizden_detay.php?kod=23161\&tipi=17\&sube $=0>$ [Accessed 9 March 2015]. 
Antonopoulou, G.; Dimitrellos, G.; Beobid, A. S.; Vayenas, D.; Lyberatos, G. 2015. Chemical pretreatment of sunflower straw biomass: The effect on chemical composition and structural changes. Waste Biomass Valorization 6(5):733-746.

Bonilla, J. L.; Chica, A.; Ferrer, J. L; Jimenez, L.; Martin, A. 1990. Sunflower stalks as a possible fuel source. Fuel 69(6):792-794.

Chen, Y.; Sharma-Shivappa, R. R. 2007. Potential of agricultural residues and hay for bioethanol production. Appl Biochem Biotechnol 142(3): 276-290.

Copur, Y.; Tozluoglu, A.; Balaban, M.B. 2013a. $\mathrm{NaBH}_{4}$ pretreatment in bioethanol production of corn stalks. J Wood Chem Technol 33(2):125-143.

Copur, Y.; Tozluoglu, A.; Ozkan, M. 2013b. Evaluating pretreatment techniques for converting hazelnut husks to bioethanol. Bioresour Technol 129:182-190.

Copur, Y.; Tozluoglu, A.; Ozyurek, O. 2012. Sodium borohydrate $\left(\mathrm{NaBH}_{4}\right)$ pretreatment for efficient enzymatic saccharification of wheat straw. Bioresour Technol 107:258-266.

Copur, Y.; Tozluoglu, A. 2007. The effect of AQ and $\mathrm{NaBH}_{4}$ on bio-kraft delignification (Ceriporiopsis subvermispora) of brutia pine chips. Int Biodeterior Biodegradation 60(2):126-131.

Díaz, M.J.; Cara, C.; Ruiz, E.; Pérez-Bonilla, M.; Castro, E. 2011. Hydrothermal pretreatment and enzymatic hydrolysis of sunflower stalks. Fuel 90(11):3225-3229.

Eom, I. Y.; Yu, J. H. 2015. Structural characterization of the solid residue produced by hydrothermal treatment of sunflower stalks and subsequent enzymatic hydrolysis. $J$ Ind Eng Chem 23:72-78.

Fan, L.T.; Gharpuray, M.M.; Lee, Y.H. 1987. Cellulose hydrolysis. vol. 3. Springer- Verlag, Berlin, Germany, pp. 1-68.

Farid, M. A.; Shaker, H. M.; El-Diwany, A. I. 1983. Effect of peracetic acid, sodium hydroxide and phosphoric acid on cellulosic materials as a pretreatment for enzymatic hydrolysis. Enzyme Microb Tech 5(6):421-424.

Gaspar, M.; Juhasz, T.; Szengyel, Z.; Recaey, K. 2005. Fractionation and utilization of corn fibre carbohydrates. Process Biochem 40(3-4):1183-1188.

Jimenez, L.; Bonilla, J.L. 1993. Acid-hydrolysis of sunflower residue biomass. Process Biochem 28(4):243-247.

Lee, Y.H.; Fan, L.T. 1982. Kinetic studies of enzymatic hydrolysis of insoluble cellulose: analysis of the initial rates. Biotechnol Bioeng 24(11):2383-2406.

Liu, S.; Fang, G.; Wang, Q.; Deng, Y.; Han, S. 2011. Kinetic modeling of enzymatic hydrolysis of poplar waste by wet oxidation pretreatment. BioRes 6(4):4229-4237.

López, F.; García, J.C.; Pérez, A.; Feria, M.J.; Zamudio, M.; Garrote, G. 2010. Chemical and energetic characterization of species with a high-biomass production: fractionation of their components. Environ Prog Sustain 29(4):499-509.

Lu, Y. P.; Yang, B.; Gregg, D.; Saddler, J. N.; Mansfield, S. D. 2002. Cellulase adsorption and an evaluation of enzyme recycle during hydrolysis of steam-exploded softwood residues. Applied Biochem Biotechnol 98 (100):641-654. 
Marechal, V.; Rigal, L. 1999. Characterization of by-products of sunflower culture-commercial applications for stalks and heads. Ind Crop Prod 10 (3):185-200.

Monlau, F.; Trably, E.; Barakat, A.; Hamelin, J.; Steyer, J. P.; Carrere, H. 2013. Two-stage alkaline-enzymatic pretreatments to enhance biohydrogen production from sunflower stalks. Environ Sci Technol 47(21):12591-12599.

Ohgren, K.; Bura, R.; Saddler, J.; Zacchi, G. 2007. Effect of hemicellulose and lignin removal on enzymatic hydrolysis of steam pretreated corn stover. Bioresour Technol 98(13):2500-2510.

Ruiz, E.; Cara, C.; Ballesteros, M.; Manzanares, P.; Ballesteros, I.; Castro, E. 2006. Ethanol production from pretreated olive tree wood and sunflower stalks by an SSF process. Applied Biochem Biotechnol 129(132):631-643.

Ruiz, E.; Cara, C.; Manzanares, P.; Ballesteros, M.; Castro, E. 2008. Evaluation of steam explosion pre-treatment for enzymatic hydrolysis of sunflower stalks. Enzyme Microb Tech 42(2):160166.

Ruiz, E.; Romero, I.; Moya, M.; Cara, C.; Vidal, J.D.; Castro, E. 2013. Dilute sulfuric acid pretreatment of sunflower stalks for sugar production. Bioresour Technol 140:292-298.

Sharma, S.K.; Kalra, K.L.; Grewal, H.S. 2002. Enzymatic saccharification of pretreated sunflower stalks. Biomass Bioenerg 23(3):237-243.

Silverstein, R.A.; Chen, Y.; Sharma-Shivappa, R.R.; Boyette, M.D.; Osborne, J. 2007. A comparison of chemical pretreatment methods for improving saccharification of cotton stalks. Bioresour Technol 98(16):3000-3011.

Sluiter, A.; Hames, B.; Ruiz, R.; Scarlata, C.; Sluiter, J.; Templeton, D. 2004. Determination of structural carbohydrates and lignin in biomass. Biomass Analysis Technology Team Laboratory Analytical Procedures. National Renewable Research Laboratory, Golden, Colorado.

Soto, M.L.; Dominguez, H.; Nunez, M. J.; Lema, J.M. 1994. Enzymatic saccharification of alkali-treated sunflower hulls. Bioresour Technol 49(1):53-59.

Sreenath, H.K.; Koegel, R.G.; Moldes, A.B.; JeFries, T.W.; Straub, R.J. 1999. Enzymatic saccharification of alfalfa fibre after liquid hot water pretreatment. Process Biochem 35(1999):33-41.

Sun, J.X.; Xu, F.; Sun, X. F.; Xiao, B.; Sun, R. C. 2005. Physico-chemical and thermal characterization of cellulose from barley straw. Polym Degrad Stabil 88(3):521-531.

Tosun, A. 1997. Dilute acid hydrolysis of sunflower residue (cellulosic wastes) prior to enzymatic hydrolysis. Fresen Environ Bull 6:296-301.

Vaithanomsat, P.; Chuichulcherm, S.; Apiwatanapiwat, W. 2009. Bioethanol production from enzymatically saccharified sunflower stalks using steam explosion as pretreatment. Int Scholar Sci Res Innovation 3(1):88-91.

Varga, E.; Szengyel, Z.; Reczey, K. 2002. Chemical pretreatments of corn stover for enhancing enzymatic digestibility. Applied Biochem Biotechnol 98(100):73-87.

Wang, Z.; Keshwani, D.R.; Reddingz, A.P.; Cheng, J.J. 2010. Sodium hydroxide pretreatment and enzymatic hydrolysis of coastal bermuda grass. Bioresour Technol 101(10):3583-3585. 
Wingren, A.; Galbe, M.; Roslander, C.; Rudolf, A.; Zacchi, G. 2005. Effect of reduction in yeast and enzyme concentration in a simultaneous saccharification-and-fermentation-based bioethanol process. Applied Biochem Biotechnol 121(124):485-499.

Yang, B.; Wyman, C. E. 2004. Effect of xylan and lignin removal by batch and flow through pretreatment on the enzymatic digestibility of corn stover cellulose. Biotechnol Bioeng 86(1):88-95. 